\title{
Discussion on the Countermeasures to Optimize the University Personnel File Management Chaohua Deng
}

\author{
Jingdezhen ceramic University
}

Qiushi Road Xianghu village in XianghuTown, Fuliang County,Jingdezhen city ,Jiangxi Province

490355887@163.com

\section{Keywords: Universities; Personnel file; Management; Problem; Optimization strategy}

\begin{abstract}
University personnel files are formed during the higher education activities, including facultys', research specialists', instructional assistants', university administrators'. With the continuous expansion of the scale of higher education, the grow in number of faculty and staff and the increase of personnel file management, some deficiencies appeared, such as archives construction sites are substandard, archivists are unprofessional, management process of the personnel files is in chaos, and so on. Therefore, first of all, to analyze the causes of the problems in the personnel file management, and then find out the solution to the optimization of countermeasures.
\end{abstract}

\section{The Background of the Problem}

College personnel files mainly recorded in college staff's life, work and learning experience, reflect the age, nationality, education, political affiliation, age and other information, is an important basis for university personnel, the Organization Department of the employment of teachers, teacher evaluation, promotion of administrative cadres. Therefore, the management of personnel files needs special place, professional archivists,

At the same time have a supporting management system, in order to achieve the orderly management of personnel files. Many colleges and universities personnel file management is not satisfactory, and even there are many loopholes in management.

\section{Some Problems in the Management of Personnel Files in Colleges and Universities}

The Construction of Archives Is Substandard. Some college administrators believe that university should concentrate on teaching management and teaching management services, he construction of teaching buildings, laboratories, library, and museum to ignore the construction of personnel archives storehouse. But the material properties of personnel files is decided only to put moisture, mildew, in a well-ventilated place, in order to ensure the file intact, so need special places for safekeeping.

With the expansion of higher education, the number of some university teachers are far more than thousands, some colleges and universities begin to pay attention to the construction of teachers' personnel archives storehouse, but only attach importance to the construction area, do not divide storehouse, search room and archives staff office area into three rooms. Facilities are not complete, there are only some air conditioner, does not have wet devices and firefighting equipment. Although some of them are equipped with firefighting equipment, it's too grave to be used.

Lack of professional archivists. Modern management theory believes that people are the main body of management and the object of management, which mean people is the core of management. Personnel file management is a professional work, the need for professional personnel is to ensure the completion of the management process, to ensure mistakes couldn't arise. However, there are only a small number of archives management personnel in some universities, and even lack of professionalism. Generally after a simple training, they start to work. That make personnel uneven and phenomenon unprofessional. 


\section{There Are Loopholes in the Management of Personnel Files}

The Problems of Archival Material Collection, Sorting and Filing. Due to the large size of the personnel files involved in the management sector, difficult to collect materials, and also personnel did not acquire the system knowledge of archives management, it's hard for them to identify and organize. Resulting in lack of the collected materials were collected in some archives, the need collection of materials are not complete. Archives are not comprehensive. For example, in the third categories of personnel files, each unit of the year for the identification of democratic assessment materials must be collected. However, some colleges and universities because of lacking awareness of the management of the file, there is no timely identification of democratic appraisal materials. And thought report materials which is not required to join the party filing, however.

The Loss of Files. There are several reasons for the phenomenon of lost files, one of them is transferring many times before mailing to the University. New college teachers are highly educated, some of them have been working before the doctor's graduation or master's degree, but the former institutes catalogue archives about seniority wage incompletely, resulting in disappearances, thus affecting the salary level which has directly relevance to economic self-interests of College teachers. Second is some archives staff service consciousness is not strong, who do not arrange cadre appointment approval forms and appraising materials in time. Thirdly due to the confidentiality of personal files, personal couldn't reach their files. The file holder does not know the contents of the file, even if he has lost his or her own material.

The Inconsistency of the Identity Information Front-to-back in This File. In the same person's file information, there arise a phenomenon of age, seniority, education differently. For this phenomenon, it's a kind of unconsciousness, for example, some people fill in the personal age information in this column, some write the Gregorian calendar of birth, others may write lunar calendar. Worse, files are deliberately tampered with for personal promotion. There are online reports of corruption cases that some people in order to maximize the interests of individual, rewriting age that differs widely; seniority fill in older than other different forms in the initial participation work; Making the degree of education higher, to reflect the high degree of education in the file, regardless of forging qualifications.

Ownerless Files. Colleges and universities are the areas of high level talents flow. There are some college teachers want to get better welfare from original university to other department, but because of employment contract with the original. If you get off work during the contract period, you should pay a high penalty. While some workplace in order to attract talents, setting up green channels, implementing special policies to create a now file for them. The leaving desperately teacher who want to avoid pay for the high liquidated damages, abandon the file to leave, resulting in the original university where there is no master file. Not only do abandoned files dilute the concept of people's files, but also affect the value and status of personnel files, and the normal operation of the talent market. [1]

\section{Countermeasures of Optimizing Personnel Archives Management in University}

Standardize the Construction of Archives. In view of the actual situation that personnel archives warehouse are always neglected, if the personnel archives construction is considered as one of the conditions of university evaluation, the basic facilities of warehouse are assessed as the basic conditions for acceptance, it can promote the construction of personnel archives management normatively, professionally and scientifically.

The construction of personnel archives is an important prerequisite to ensure the security of personnel files. According to the Nation in 1990 revised "cadre work regulations" the sixth chapter of archives preservation and conservation article 27, cadre archives management department should establish a solid, fireproof, moisture-proof special archives warehouse with iron cabinet. Warehouse area should be 20-25 square meters per thousand volumes. The warehouse should be equipped with air conditioners, dewetting and fire extinguisher. Therefore, to improve the conditions of the university personnel file warehouse, need the purchase of a strong, fire-proof, moisture-proof 
special iron file cabinets, equip with anti-theft, anti-light, anti-high-temperature special facilities, separate warehouse, reading room and office space. Based on the confidentiality of personnel archives, it's necessary to install security system in the warehouse and put with monitoring equipment. Keep the warehouse clean, and maintain the appropriate temperature, humidity. Requires strict control of temperature at $14-24$ degrees Celsius, relative humidity 45-65\%.

In order to intensify security and confidentiality of archives management, you can install the high-definition camera in the office area and warehouse. So that it can enhance security and also can avoid Tamper with files and so on.

\section{Build Professional File Management Team}

Increase the Number of Archivist. Personnel archives are mainly compose of resume, autobiography, identification, academic degree, title and so on, adding up to ten types. Manager should be patient and meticulous. And every year, each person is required to file the third types of annual evaluation forms and ninth types of wage records. After new teachers come to school, the audit work of teachers' qualification materials need to be; After the annual evaluation, this kind of materials also need to be archived which is an important basis for assessment of a higher level of professional titles in the future; Ninth kinds of materials are salary, are an important basis for the up and posts grading, even after retirement approval. Workload is heavy and important, once making mistakes, which is likely to affect the personal interests of the staff. Personnel in addition to collect, classify, arrange and file materials, also need to complete new personnel archives catalogue written into the work, cooperate with school to complete the file query, borrowing, delivery and transfer death cadre archives to archives, hardly work, so it is necessary to increase the number of personnel. Preferably according with the number of 600:1 equipped. That is, each of the 600 colleges and universities with a personnel.

Employ Professional Archivist. In the case of the conditions are ripe, it is through professional personnel that it can promote the construction of original personnel management and improve the knowledge structure of personnel. In the absence of professional background of the archives management of colleges and universities, organizing regularly training is a good way. Communication with other universities or provincial archives to learn knowledge about filing, classification, identification, research and improvement of archives protection methods and technology, learn the advanced file management mode.

Constantly Update the Knowledge of Archives Management and Strengthen the Service Consciousness of Archives. This is an age of learning for life, manager is no exception. With the development of times, the archives management work can't stay in the original manual operation level, in addition to strong political consciousness and sense of confidentiality, personnel need to coordinate the university position setting and personnel system reform, strengthen the information knowledge, the use of management software to achieve the personnel archives catalogue, the storage and transfer. Under the premise of ensuring the security and confidentiality of the personnel files, the preservation and management of archives are realized by the means of electronic and networking. For the relatively high frequency of query information, such as changes in wages approval form and cadres' approval form, can be scanned archive in the form of PDF. Personnel department and organization department are granted certain privileges to provide query services in the form of local area network. So as to avoid repeated query paper files, not only can it improve service efficiency, but it can also protect the damaged paper files. This will enable the personnel files to better serve the personnel management in Colleges and universities.

\section{Improve Each Link of Personnel Files Management}

To Establish Personnel Files Collection Network. In order to ensure the daily collection of personnel files in Colleges and universities, we can establish the data collection network system of personnel files. For example, in order to collect third types of annual assessment materials, each department should determine the liaison to submit files in early June every year. Collecting fifth and 
sixth party political material, also has to strengthen contact with organization departments, as well as the corresponding liaison, so that a specific duty is to a specific person. Making personnel archives organization, collection, identification, sorting, archiving, transfer form system, each department shall designate a person to collect information on the personnel files and be trained by the human resource department. [2]

To Ensure the Integrity of the Personnel Files. For the process of file management, the phenomenon of lost files can be circumvented from the national, local and individual file management system design. National personnel archives administrative department form system of the loss accountability. A specific duty is to a specific person who should file the materials, if losing, they should take administrative responsibility and undertake the corresponding administrative negligence, to reduce the error efficiency through necessary means of punishment. On the transfer of university staff, in order to ensure the completeness of the files, personnel are required to carefully check the files and find out that the materials whether are complete, especially for joining the party and salary materials. In determining the complete file information before they go through the relevant personnel transfer procedures. At the individual level, the popularity of archival knowledge is useful. Many people do not know what kind of personal information will be included in their files, and what information must be stored in the file. In addition to the confidentiality of China's file management, individuals do not have the right to know their own files, due to the lack of personal file knowledge, I didn't know losing my information.

To Cross-Check the Employee's Identity Information. First of all for new incoming staff, require them to fill out a new cadre resume. To determine their age, place of origin, political outlook, education, seniority, work experience and other basic identity information. As for age or seniority is inconsistent, verify identity cards, household registration and other information. In the latest cadre resume notes in particular that it is accurate identity information, affix the seal of the personnel management department. Second, in order to facilitate the management of day-to-day work, the staff of the school's basic information adopt electronic information management. The core of the construction and service of personnel file information in colleges and universities is to establish a database of personnel files, and use the computer to manage the personnel files in three dimensional and dynamic way. [3] The establishment of personnel files database, enabling high-file management and other departments of the school information between direct docking. Now the size of colleges and universities are large, the number of faculty, the relevant leadership is difficult to fully understand information of teachers. Under the premise of ensuring the privacy of teachers and staff do not leak, through electronic information management to achieve different permissions personnel inquiries. When schools select middle - level administrative cadres, the teaching branch selects director of the Department, the elective course starts, the school leaders, sub-leaders and students extract the basic information of candidates at any time, including the candidate's academic qualifications, degree level, professional background, margin structure, it's easy to improve the file query speed, it can quickly improve work efficiency. It can serve better the teaching management of colleges and universities. Again, making personnel file inquiry and borrow approval procedures strict. In order to avoid tampering with the file behavior, if someone want to check and borrow personal files, she get agreements from the organization and personnel department, she need to be registered in the book. During inspection process there is video surveillance, and accompanied by the completion of the archives. In the process of adjustment of cadres in Colleges and universities, in order to get the promotion, thus faking file phenomenon, once discovered, in accordance with the relevant provisions of the state "Archives Law" and "security law", the individual and provide convenience fraud personnel will receive the corresponding criminal responsibility to prevent the occurrence of fraud personal information behavior.

Improve Personnel Assessment Mechanism to Put an End to Abandoned Files. From one aspect, the non - master file of university reflects the problem of the assessment mechanism. Some highly educated people believe that there are dual pressures of teaching and research in colleges and universities, and evaluation of titles is difficult, pay progress is slow. They have no choice but to leave. Discarding files will not only result in brain drain, but also affect the stability of university 
teachers. With highly educated and high-capacity talented person don't worry about losing job under the market economy system. But the newly established personnel files, there is no original as a basis for its authenticity. Therefore, colleges and universities should improve the assessment mechanism for highly educated personnel. In the examination of university teachers, based on the teaching post, the nature of the post of scientific research posts, implementing differentiated job evaluation methods. Timely improve the salaries of faculty and staff, care about teachers and students at work and life, emotionalize them. Implementation of the truly flexible management and stability of the teaching staff are to avoid the phenomenon of abandoning files.

\section{Conclusion}

Personnel achieves management is an indispensable link in the personnel management of colleges and universities. Personnel file management, not just for some of the paper management, is the real writing of these paper masters of the historical management. In the management process, it is necessary to focus on the construction of hardware facilities, but also pay attention to software updates. It is necessary to pay attention to the perfection of the personnel file management system, but also popularize the relevant knowledge of archival law, but also should pay attention to flexible management to emotionalize people.

\section{References}

[1] S.Y. Wang: The Research and Countermeasures of the phenomenon of the abandonment of personnel files in Universities. Journal of Jingdezhen Higher College, (2007) No.9, p.47-48

[2] X.M. Zhen: Fixation management of Personnel files. Electric Power Technology of Xinjiang, (2012) No.3, p.60

[3] Z.F. Wu: The new problems and reform path of personnel archives management in Colleges and Universities Administrative Management in China, (2013) No.6, p.100 